
дыхания

\title{
Sh.Z.Zagidullin \\ Results of XXI Russian Congress on respiratory diseases
}

В 2011 г. XXI Национальный конгресс по болезням органов дыхания впервые прошел в столице Республики Башкортостан - Уфе - с 25 по 28 октября.

21 год тому назад ведущими пульмонологами страны во главе с директором НИИ пульмонологии МЗ РФ, главным пульмонологом МЗ РФ, акад. РАМН, проф. А.Г.Чучалиным было инициировано проведение ежегодных национальных конгрессов по болезням органов дыхания, в которых принимали бы активное участие не только российские, но и зарубежные ученые. Необходимость организации этого форума практических врачей и ученых, работающих в различных отраслях пульмонологии, обусловлена широким распространением патологии респираторной системы, значительным экономическим ущербом вследствие потери трудоспособности, инвалидизации и смертности населения от данных заболеваний.

Оглядываясь назад, можно утверждать, что итоги прошедших конгрессов немало способствовали организации терапевтической и пульмонологической служб, решению актуальных проблем диагностики, лечения, реабилитации и профилактики болезней органов дыхания на территории всей страны, а также интеграции российских и зарубежных ученых.

Для вовлечения максимального количества врачей в образовательный процесс Российское респираторное общество - РРО (председатель - акад. РАМН, проф. А.Г.Чучалин) сознательно расширяет географию мест проведения конгрессов. За прошедшие годы они проходили в Киеве, Москве, СанктПетербурге, Новосибирске, Челябинске, Казани, Екатеринбурге.

Предложение о проведении конгресса в Уфе впервые было высказано акад. А.Г. Чучалиным во время выездной научной сессии НИИ пульмонологии ФМБА России, которая прошла в столице Башкортостана 29 февраля 2010 г. Эта конференция, на которой обсуждались наиболее актуальные вопросы пульмонологии, вызвала большой интерес у медицинской общественности.

Окончательно решение о проведении форума в Уфе было принято во время юбилейного ХХ Конгресса, который состоялся в Москве в ноябре 2010 г. В феврале 2011 г. акад. А.Г.Чучалин от имени Российского респираторного общества (РРО) направил обращение к президенту Республики Башкортостан
P.З.Хамитову с аргументированным предложением о проведении очередного Конгресса в Уфе.

Были получены положительные отклики со стороны президента, республиканского Министерства здравоохранения и Башкирского государственного медицинского университета (БГМУ). А.Г.Чучалин обсудил с министром здравоохранения РБ Г.А.Шебаевым и ректором БаГМУ, проф. В.Н.Павловым идеологию, формат и организационные условия проведения Конгресса, и после этого оргкомитет в составе президиума PРО и ученых БГМУ начал большую трудоемкую работу по формированию научной программы. Масштабность данного мероприятия потребовала проведения 2 рабочих совещаний оргкомитета в Москве. Учитывая многообразие научных направлений, по каждому из них были назначены ответственные лица из числа ведущих специалистов. Наполнение программы Конгресса продолжалось практически с апреля по конец сентября 2011 г. Одновременно в Уфе были изданы приказы Министерства здравоохранения РБ и БГМУ о проведении Конгресса, в которых был обозначен оргкомитет форума от РБ и определен комплекс мероприятий по его проведению. На всех этапах подготовки большую организационно-методическую помощь оказывало руководство БГМУ, особенно ректор - проф. В.Н.Павлов, проректор по научной и лечебной работе - проф. М.А.Нартайлакова, проректор по воспитательной работе - проф. В.Л.Юлдашев, проректор по учебной работе - доц. А.А.Цыглин, директор ИПО - проф. М.С.Кунафина и др.

24-28 сентября 2011 г. в Амстердаме прошел XXI Европейский респираторный конгресс, в котором приняли участие делегаты из Башкортостана. Всего на этом мероприятии были зарегистрированы 22220 делегатов. В изданный по результатам форума сборник вошел 4331 тезис. За 5 дней Конгресса состоялись 388 научных сессий, с лекциями и дискуссиями выступили 350 лекторов, были проведены 13 рабочих совещаний, 25 симпозиумов, 20 курсов последипломного образования врачей. Башкирские ученые представили на Конгрессе 7 докладов на электронной и постерной сессиях, опубликовали в сборнике более 10 тезисов. Большой вклад в научную программу форума внесли проф. Ш.З.Загидуллин, Р.Х.Зулкарнеев, У.Р.Фархутдинов и др. 
Большой интерес у делегатов Конгресса традиционно вызвала "Национальная деревня". Большой популярностью пользовался стенд РРО, где состоялась презентация XXI Национального конгресса по болезням органов дыхания в Уфе. Здесь были представлены материалы РРО, информация и видеофильм о Башкортостане. Делегатов Европейского конгресса встречали председатель РРО акад. А.Г.Чучалин, проф. С.И.Овчаренко, проф. С.Н.Авдеев, проф. М.М.Илькович, проф. З.Р.Айсанов, проф. А.А.Визель, проф. Р.С.Фассахов, проф. Е.И.Шмелев, проф. В.И.Трофимов, проф. И.В.Лещенко и многие другие ведущие пульмонологи России. Стенд курировали проф. Ш.З.Загидуллин и У.Р.Фархутдинов. В подготовке материалов для научной программы Европейского конгресса и презентации большое участие приняли проф. Р.Х.Зулкарнеев, Н.Ш.Загидуллин и др.

Конгресс в Уфе был открыт с 8:00 до 19:00, работа велась одновременно в 7 аудиториях конгресс-холла и аудитории корпуса № 10 БГМУ. Большое впечатление на делегатов произвело выступление президента Башкортостана P.З.Хамитова на церемонии открытия. Впервые за период проведения Конгресса в регионах президент республики представил глубокий аналитический доклад, в котором с системных позиций рассматривались современные тенденции развития здравоохранения в нашей стране и, в частности, в Башкортостане. Р.З.Хамитов обозначил перед учеными и практическим здравоохранением РБ ряд актуальных проблем, требующих подробного изучения. Они касаются вопросов медицинской статистики, неоднозначных результатов представления данных о распространенности бронхолегочных заболеваний в различных районах и городах Башкирии, оценки показателей здоровья населения и др. В беседе с акад. А.Г. Чучалиным президент РБ Р.З.Хaмитов высказал пожелание о необходимости расширения сотрудничества практического здравоохранения и научных школ Башкортостана с НИИ пульмонологии в деле повышения качества оказания медицинской помощи больным с патологией органов дыхания.

На открытии Конгресса председатель РРО акад. А.Г. Чучалин вручил врачам награды за заслуги в изучении болезней органов дыхания. Главную награду получили зав. кафедрой терапии Саратовской военно-медицинской академии проф. М.М.Кириллов и зав. кафедрой педиатрии 1-го Московского государственного медицинского университета проф. H.A.Геnne, а также зав. отделением пульмонологии ГКБ № 21 г. Уфы проф. У.Р.Фархутдинов. Почетных грамот РРО за многолетний безупречный труд и научные достижения по проблеме бронхолегочных заболеваний были удостоены зав. кафедрой фтизиопульмонологии БГМУ, проф. Х.К.Аминев и зав. пульмонологическим отделением РКБ им. Г.Г.Куватова О.А.Богородицкая.

Конгрессы по болезням дыхания традиционно проходят по европейским стандартам. В первый же день форума были проведены 15 школ по проблемам болезней органов дыхания. Основная программа включила в себя 62 симпозиума, 2 интернет-сессии, 20 лекций ведущих специалистов, 2 круглых стола, клинические разборы и т. п. Такое разнообразие форм проведения и тематики Конгресса реально отражает мультидисциплинарность пульмонологии.

Следует отметить, что Конгресс вызвал необычайно широкий резонанс среди медицинской общественности как в целом по стране, так и в Башкирии. Достаточно сказать, что за дни проведения форума его посетили более 4800 участников, были зарегистрированы 800 делегатов из всех регионов страны от Калининграда до Дальнего Востока. Присутствовали и зарубежные ученые из США, Германии, Норвегии, Бельгии.

В работе Конгресса активное участие приняли врачи различных специальностей: терапевты и педиатры, пульмонологи и аллергологи, организаторы здравоохранения, фтизиатры, торакальные хирурги, онкологи, микробиологи, эндоскописты, специалисты по функциональной диагностике, восстановительной медицине и курортологии и др.

Особенностью конгрессов является постоянное совершенствование форм его проведения. Наряду с традиционными формами, такими как пленарные и секционные заседания, рабочие совещания экспертного совета РРО, мастер-классы, в этом году состоялись сессии с использованием информационных технологий. Также Конгресс стал площадкой для информирования о последних достижениях ведущих отечественных и зарубежных фармацевтических компаний и производителей медицинского оборудования.

РРО уделяет большое внимание подготовке молодых врачей-пульмонологов - как в научном, так и практическом отношении. 12 молодых ученых, прибывших на Конгресс, активно участвовали в работе симпозиумов в качестве сопредседателей, в заседании клуба молодых ученых, выступили с научными сообщениями. В последние годы акад. А.Г.Чучалин декларирует среди молодежи идею сдачи международного сертификационного экзамена по болезням органов дыхания по программе HERMES, и Конгресс в Уфе стал одним из этапов подготовки к этому испытанию. На Конгрессе был организован конкурс молодых ученых, на котором они представили постеры и доклады. Победители получили именные премии РРО.

Обширная программа Конгресса включала обсуждение наиболее актуальных проблем детской и взрослой пульмонологии, среди которых необходимо отметить диагностику, лечение и реабилитацию важнейших заболеваний бронхо-легочной системы: пневмонии, в т. ч. гриппозной этиологии, бронхиальной астмы, хронической обструктивной болезни легких, муковисцидоза, врожденных аномалий легких, ведущих респираторных синдромов (дыхательной недостаточности, респираторного дистресс-синдрома взрослых, легочной гипертензии), туберкулеза легких, рака легких, внедрение современных технологий в грудной хирургии, анестезиологии и реаниматологии, профилактику болезней 
органов дыхания, разработку комплексных профилактических, в т. ч. антисмокинговых программ, вопросы экологической пульмонологии и др.

Особое внимание на Конгрессе было уделено организационным вопросам диагностики, лечения и профилактики болезней органов дыхания, внедрению рекомендаций Европейского и Российского респираторных обществ и других информационнометодических материалов.

Учитывая важную роль среднего медицинского персонала в лечебно-диагностическом процессе у больных с патологией органов дыхания, в рамках Конгресса была организована специальная школа, посвященная этой теме, под руководством проф. Р.Х.Зулкарнеева и директор Центра повышения квалификации медицинских сестер МЗ РБ доц. В.Ф.Шакирова.

Для развития новых форм взаимодействия и дальнейшей интеграции пульмонологии с общетерапевтической сетью состоялась научно-практическая конференция терапевтов РБ, на которой обсуждались вопросы тесной взаимосвязи болезней органов дыхания с другими терапевтическими специальностями. В подготовке и проведении этой конференции большую роль сыграли председатель ассоциации терапевтов РБ проф. А.Б.Бакиров и зав. кафедрами терапии БГМУ.

Главной особенностью прошедшего Конгресса явилось то, что он был направлен на повышение образовательного уровня не только врачей специалистов по болезням органов дыхания - пульмонологов, аллергологов, фтизиатров, торакальных хирургов и др., но и в первую очередь врачей первичного звена здравоохранения - участковых терапевтов, педиатров, семейных врачей и др.
Следует отметить активное участие в работе форума ученых БГМУ и практических врачей из Башкортостана. Достаточно сказать, что ведущие представители научного сообщества республики приняли участие в проведении 3 школ пульмонолога, 25 симпозиумов, прочитали 4 лекции, были сопредседателями 19 симпозиумов, представили 44 доклада от 73 соисполнителей.

По итогам Конгресса акад. А.Г. Чучалин от имени РРО выразил признательность его организаторам за успешное проведение научной и культурной программ.

Следует подчеркнуть, что проведение Конгресса стало возможным благодаря созидательной деятельности ведущих пульмонологов страны-членов РРО во главе с акад. А.Г. Чучалиным, Министерства здравоохранения РБ и Управления здравоохранения г. Уфы. Особо хотелось бы отметить неоценимый вклад ректората БГМУ, профессорско-преподавательского состава, кафедры пропедевтики внутренних болезней, а также клинических ординаторов, интернов и студентов-волонтеров, оказавших большую помощь в техническом сопровождении различных мероприятий, в подготовке и проведении Конгpecca.

Нет сомнений, что итоги XXI Национального конгресса по болезням органов дыхания будут способствовать оптимизации оказания медицинской помощи больным пульмонологического профиля и укреплению отечественных медицинских традиций. Впереди большая работа по претворению идей Конгресса в научную и практическую деятельность.

Информация об авторе

Загидуллин Шамиль Зарифович - д. м. Н., проф., президент XXI Национального конгресса по болезням органов дыхания; тел.: 8-917-442$48-63$ 